Check for updates

Cite this: RSC Adv., 2017, 7, 33494

Received 9th April 2017

Accepted 20th June 2017

DOI: $10.1039 / \mathrm{c} 7 \mathrm{ra0} 4024 \mathrm{e}$

rsc.li/rsc-advances

\section{Synthesis and color properties of novel polymeric dyes based on grafting of anthraquinone derivatives onto $\mathrm{O}$-carboxymethyl chitosan}

\author{
Dongjun Lv, ${ }^{\text {ac }}$ Jin Cui, ${ }^{\text {}}$ Yufang Wang, ${ }^{d}$ Guohua Zhu, ${ }^{a}$ Mingjie Zhang (D) *a \\ and Xiujing $\mathrm{Li}^{\mathrm{C}}$
}

Four polymeric dyes were prepared by grafting brominated anthraquinone derivatives onto $O$ carboxymethyl chitosan through Ullmann condensation. The chemical structure of the prepared polymeric dyes was determined by Fourier transform infrared spectroscopy (FT-IR), elemental analysis and differential scanning calorimetry (DSC), and the results showed that the anthraquinone derivatives were successfully grafted onto $\mathrm{O}$-carboxymethyl chitosan. The grafting degrees of the four polymeric dyes were $0.66,1.14,0.93$ and $1.01 \mathrm{mmol} \mathrm{g}^{-1}$ respectively. The color performance of brominated anthraquinone derivatives and prepared polymeric dyes was determined and compared using digital photographs and UV-Vis adsorption spectra, and it was found that the electronic properties and planarity of the substituent group in the anthraquinone derivatives obviously affected the adsorption wavelength of the prepared polymeric dyes. In addition, the polymeric dyes with an electron donating group and higher planarity showed longer adsorption wavelengths and more deep color. The cytotoxicity of prepared polymeric dyes was tested, and their $\mathrm{IC}_{50}$ values on human liver cell lines LO2 were 7.666, $8.557,8.186$ and $8.934 \mathrm{~g} \mathrm{~L}^{-1}$ respectively, suggesting low cytotoxicity of the prepared polymeric dyes.

\section{Introduction}

Polymeric dyes are a new type of dye with organic dyes introduced into the main or side chains of polymers by chemical reactions. Polymeric dyes integrate characteristics of both dyes and polymers, and also offer excellent solvent resistance, thermal and chemical stability, biocompatibility and good color fastness. ${ }^{1-3}$ In addition, they are non-absorbable by the gastrointestinal tract, which obviously improves their safety in the human body. ${ }^{4}$

Generally, most synthetic food dyes are azo compounds. However, due to their harm to human health, particularly when they are excessively consumed, the edible azo dyes have been gradually banned and their usage seriously restricted. ${ }^{5}$ Thus, it is necessary to find some new species of edible colorants for the replacement of presently used azo food dyes. Anthraquinone dyes and their derivatives are species of colorants with excellent color properties, and they are widely used as dyes and pigments, ${ }^{6,7}$ and colorants in cosmetics, drugs and foods. ${ }^{8-10}$ Furthermore, they have a variety of interesting biological

${ }^{a}$ Department of Chemistry, School of Science, Tianjin University, Tianjin 300354, China.E-mail: mjzhangtju@163.com

${ }^{b}$ National Foodstuff Inspection Center, Tianjin Product Quality Inspection Technology Research Institute, Tianjin 300384, China

'Shandong Yu Hong New Pigment Co., Ltd., Dezhou 253000, China

${ }^{d}$ Shi Jia Zhuang University of Applied Technology, Shijiazhuang 050081, China activities and pharmacological effects, such as antiviral,11 antioxidant, ${ }^{12,13}$ antibacterial, ${ }^{14,15}$ anti-cancer ${ }^{16,17}$ and anti-inflammatory, ${ }^{\mathbf{1 8 , 1 9}}$ and to prevent osteoporosis and hypoglycemic activity. ${ }^{20,21}$

Based on the advantages of anthraquinone derivatives, we intend to graft them to high molecular materials to fabricate polymeric dyes. As reported in our previous work, ${ }^{22}$ the $\mathrm{O}$-carboxymethyl chitosan is an optimal carrier due to their good water solubility and biological compatibility. ${ }^{23-25}$ In this paper, anthraquinone derivatives were firstly brominated, and then grafted onto the $O$-carboxymethyl chitosan by Ullmann condensation to obtain polymeric dyes. The chemical structure of prepared polymeric dyes was determined by Fourier transform infrared spectroscopy (FT-IR), elemental analysis and differential scanning calorimetry (DSC), and the color performance and adsorption properties of anthraquinone derivatives and prepared polymeric dyes were determined and compared by digital photographs and UV-Vis adsorption spectra. Eventually, the toxicity of prepared polymeric dyes was tested by a cytotoxicity experiment on normal human liver cell lines LO2.

\section{Results and discussion}

Characterization of prepared polymer dyes

FT-IR spectral analysis. FT-IR spectra of polymeric dyes 1-4 are shown in Fig. 1. The characteristic absorption peaks at 1621-1637 and $1384-1420 \mathrm{~cm}^{-1}$ were corresponded to carbonyl 

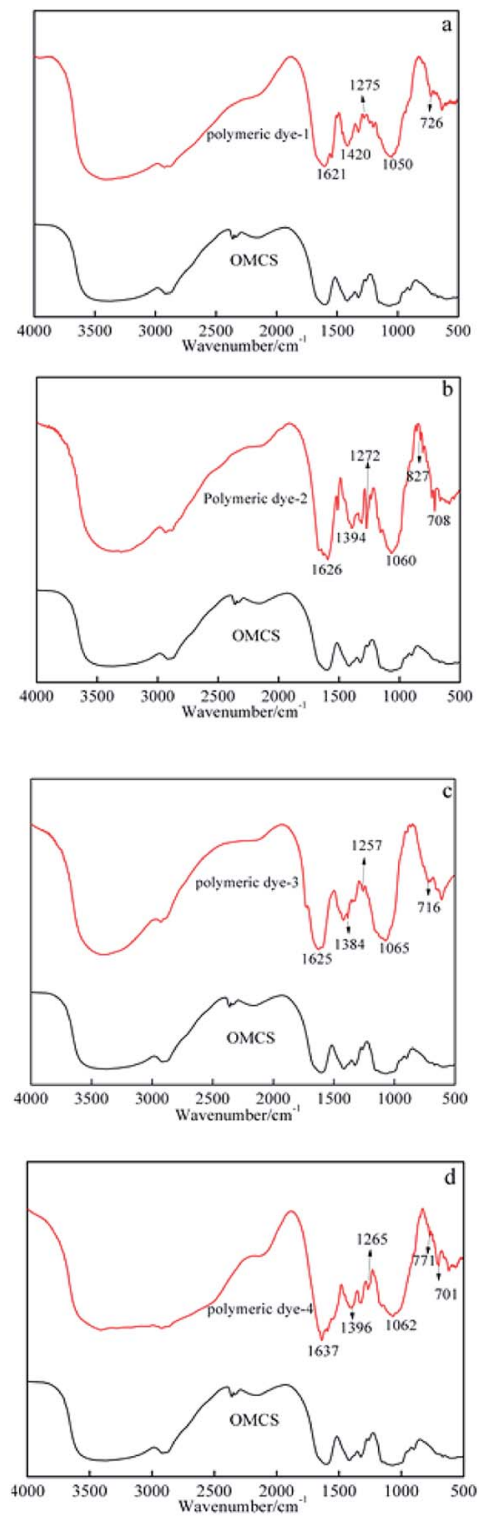

Fig. 1 FT-IR spectra of polymeric dye-1 (a), dye-2 (b), dye-3 (c) and dye-4 (d).

group absorption in anthraquinone structure $^{26}$ and $\mathrm{C}=\mathrm{C}$ absorption peak in aromatic ring respectively. The absorption peak at $701-827 \mathrm{~cm}^{-1}$ revealed $=\mathrm{C}-\mathrm{H}$ bending vibration absorption outside the plane. From the chemical structure of the four prepared polymeric dyes, it could be found that the anthraquinone derivatives grafted onto the $\mathrm{O}$-carboxymethyl chitosan through $\mathrm{C}-\mathrm{N}$ bond, and its stretching vibration at $1257-1275 \mathrm{~cm}^{-1}$ was observed. In addition, there was a sulfonate group in the four prepared polymeric dyes, and the characteristic peak at $1050-1065 \mathrm{~cm}^{-1}$ corresponded to $-\mathrm{SO}_{3}$ stretching vibration was also observed. From the analysis results mentioned above, it was concluded that anthraquinone derivatives were successfully grafted onto OMCS through Ullmann condensation.

Elemental analysis. The grafting degree of anthraquinone derivatives onto OMCS in the four prepared polymeric dyes were determined by elemental analysis, and the results were listed in Table 1 . For polymeric dye-1, according to the change in the $\mathrm{S}$ content, the grafting degree could be calculated as $\mathrm{S} \% / M_{\mathrm{S}} / 1 \mathrm{~g}=$ $0.66 \mathrm{mmol} \mathrm{g}^{-1}$. Similarly, for the polymeric dye-2, dye-3 and dye-

Table 1 Elemental analysis results of the prepared polymeric dyes

\begin{tabular}{lllll}
\hline & \multicolumn{4}{l}{ Elemental content/\% } \\
\cline { 2 - 5 } Sample & $\mathrm{C}$ & $\mathrm{N}$ & $\mathrm{S}$ & $\mathrm{H}$ \\
\hline OMCS & 39.5 & 5.8 & & 6.0 \\
Polymeric dye-1 & 34.0 & 4.2 & 2.1 & 4.1 \\
Polymeric dye-2 & 45.1 & 4.7 & 3.3 & 3.8 \\
Polymeric dye-3 & 45.4 & 4.0 & 3.2 & 3.4 \\
Polymeric dye-4 & 49.9 & 4.1 & 2.9 & 4.2
\end{tabular}
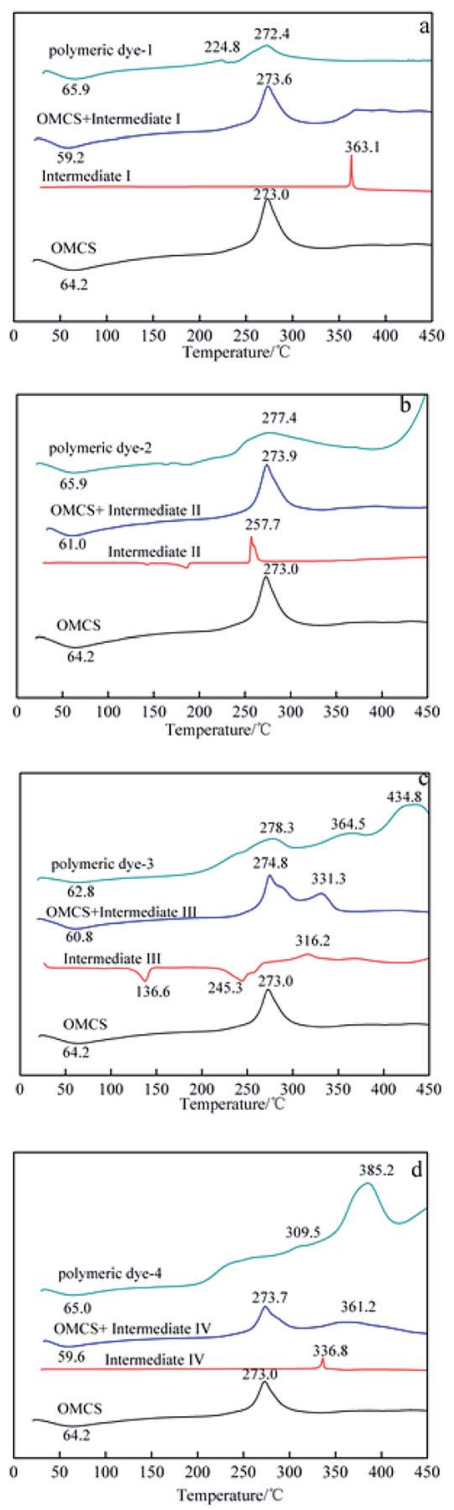

Fig. 2 DSC analysis of OMCS, physical mixture of anthraquinone intermediates and OMCS, anthraquinone intermediates and prepared polymeric dyes. 
4, according to the change in $\mathrm{S}$ and $\mathrm{N}$ content, the grafting degrees could be calculated as $\left(\mathrm{N} \% / M_{\mathrm{N}}-\mathrm{S} \% / M_{\mathrm{S}}\right) / 2 / 1 \mathrm{~g}$, it was calculated that the grafting degrees were $1.14,0.93$ and $1.01 \mathrm{mmol} \mathrm{g}^{-1}$.

DSC analysis. The DSC analysis results of OMCS, physical mixture of intermediate and OMCS, anthraquinone intermediates and the prepared polymer dyes were presented in Fig. 2. For all the samples, the endothermic peaks at 59.2-65.9 ${ }^{\circ} \mathrm{C}$ were assigned to the evaporation of free water. The exothermic peak at 363.1 ${ }^{\circ} \mathrm{C}, 257.7^{\circ} \mathrm{C}, 316.2{ }^{\circ} \mathrm{C}$ and $336.8^{\circ} \mathrm{C}$ was the degradation peak of anthraquinone intermediate I-IV. As shown in Fig. 2a, for polymeric dye-1 there were two exothermic peaks at $224.8^{\circ} \mathrm{C}$ and $272.4{ }^{\circ} \mathrm{C}$. However, for the physical mixture of anthraquinone intermediate I and OMCS, only one exothermic peak at 273.6 ${ }^{\circ} \mathrm{C}$ was observed, suggesting that the anthraquinone intermediate I formed a chemical bond with OMCS rather than a physical mixture. As shown in Fig. 2b, in the curve of physical mixture of anthraquinone intermediate II and OMCS, an exothermic peak at $273.9^{\circ} \mathrm{C}$ was observed, which was similar to that of OMCS. And in the curve of polymeric dye-2, the exothermic peak was shifted to $277.4{ }^{\circ} \mathrm{C}$, illustrating the formation of a chemical bond between anthraquinone intermediate II and OMCS. Similarly, it could be seen form Fig. 2c and $\mathrm{d}$ that in the curve of polymeric dye- 3 two higher exothermic peaks at 364.5 and $434.8{ }^{\circ} \mathrm{C}$ were observed, and in the curve of polymeric dye-4 a higher exothermic peak at $385.2{ }^{\circ} \mathrm{C}$ was also observed, the mentioned results illustrated that in polymeric dye-3 and dye-4 the intermediate III and IV formed a chemical bond rather than a physical mixture with OMCS. ${ }^{22}$

\section{Color performance and UV-Vis spectra of prepared polymeric} dyes

Color performance of anthraquinone intermediate and polymeric dyes. As shown in synthetic route of polymeric dyes, the anthraquinone intermediates grafted onto OMCS through an Ullmann condensation reaction and formed an $n-\pi$ conjugate electronic structure, which would affect the adsorption properties and color performance of polymeric dyes. Table 2 presented the digital photographs of anthraquinone intermediates and prepared polymeric dyes. It was obvious that the anthraquinone intermediates and prepared polymeric dyes showed different colors, and the color change illustrated that the chemical reaction between anthraquinone intermediates and OMCS did have happened, which was in accordance with the FT-IR and DSC analysis results.

UV-Vis spectra of anthraquinone intermediates and polymeric dye. The adsorption properties of the anthraquinone intermediates and the prepared polymeric dyes were determined by UV-Vis spectra, and the results were shown in Fig. 3.

It could be found that after grafting onto OMCS, there was an obvious red-shift on the adsorption wavelength of anthraquinone intermediates, and the maximum adsorption wavelength of intermediates I-IV red-shifted from 489, 505, 405 and $414 \mathrm{~nm}$ to $574,582,530$ and $535 \mathrm{~nm}$ respectively (Table 3). As mentioned above that the anthraquinone intermediates formed $n-\pi$ conjugate electronic structure with OMCS, and the electronic property and planarity of substituent group in anthraquinone intermediates affected the adsorption wavelength of

Table 2 Digital photographs of intermediate and polymer dyes solution

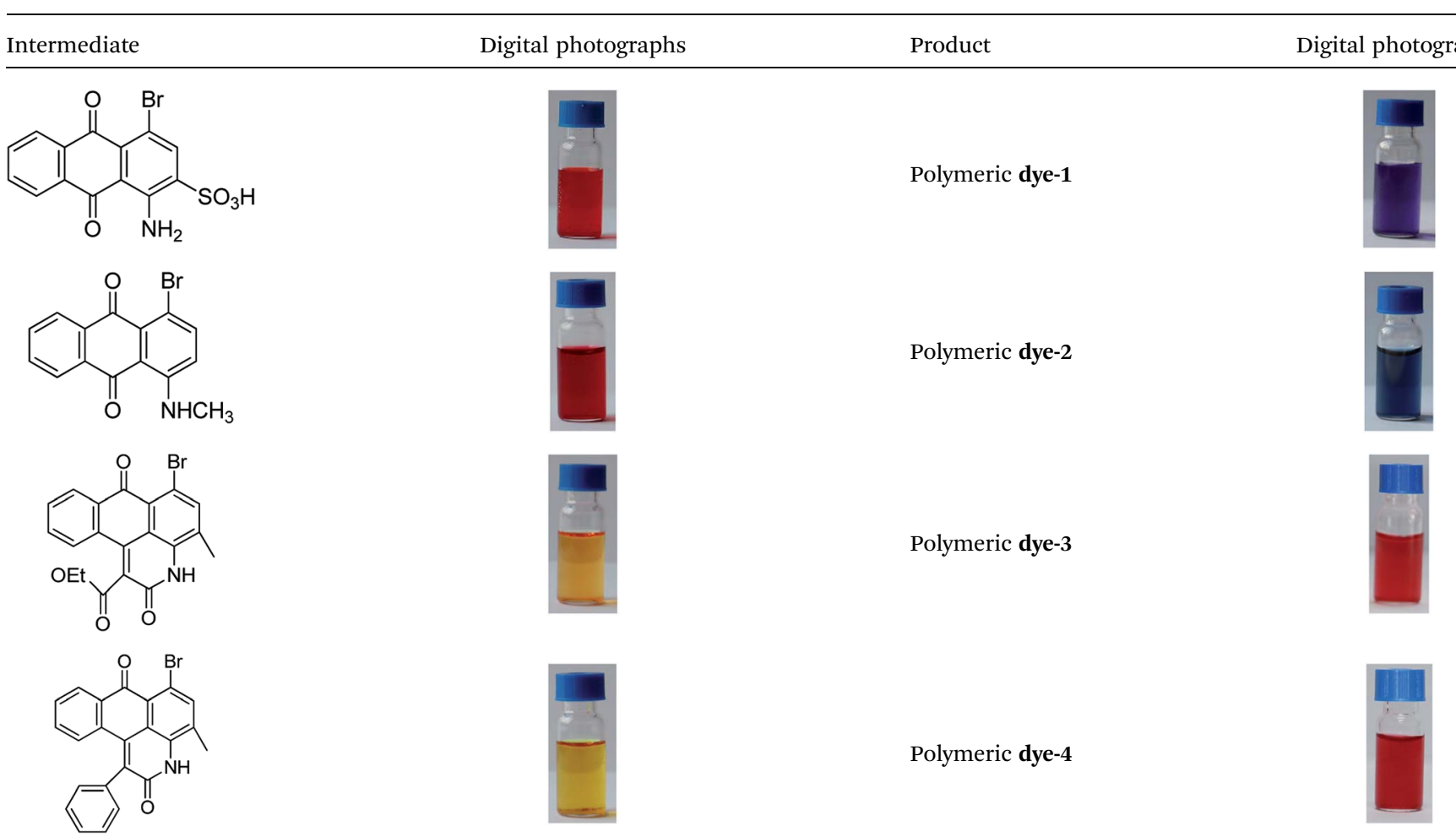



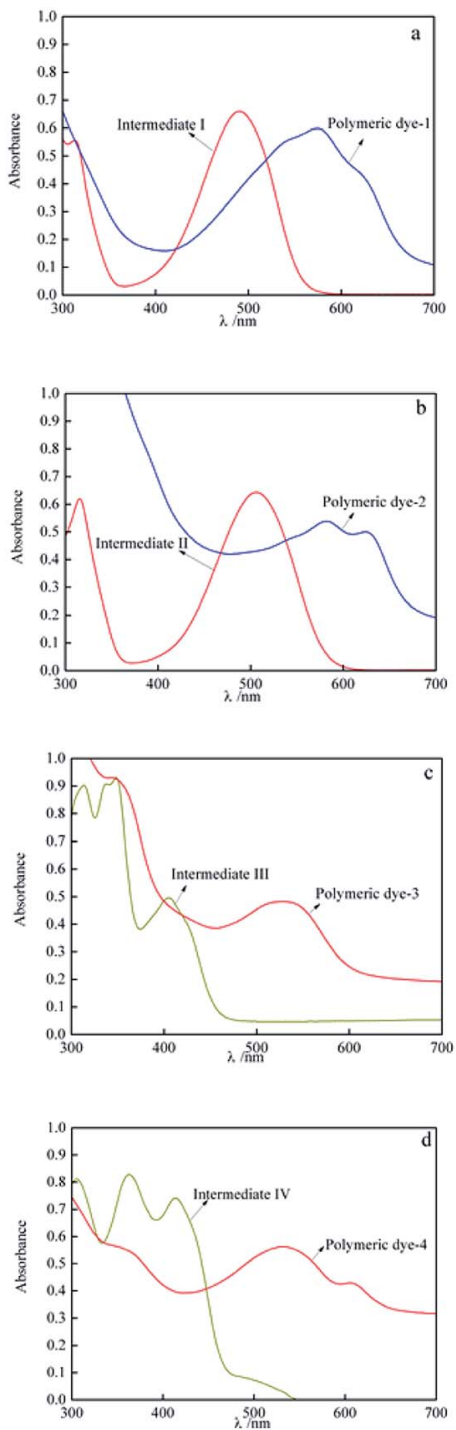

Fig. 3 The UV-Vis spectra of anthraquinone intermediates and polymeric dyes: (a) intermediate I and polymeric dye-1; (b) intermediate II and polymeric dye-2; (c) intermediate III and polymeric dye-3; (d) intermediate IV and polymeric dye-4.

Table 3 The maximum absorption wavelength of anthraquinone intermediates and polymeric dyes

\begin{tabular}{lllll}
$\begin{array}{l}\text { Anthraquinone } \\
\text { intermediates }\end{array}$ & $\lambda_{\max } / \mathrm{nm}$ & Polymeric dyes & $\lambda_{\max } / \mathrm{nm}$ & Red shift/nm \\
\hline I & 489 & Polymeric dye-1 & 574 & 85 \\
II & 505 & Polymeric dye-2 & 582 & 77 \\
III & 405 & Polymeric dye-3 & 530 & 125 \\
IV & 414 & Polymeric dye-4 & 535 & 121
\end{tabular}

the prepared polymeric dyes. For polymeric dye-1 and dye-2, the electron donating property of $-\mathrm{NH}_{2}$ and $-\mathrm{NHCH}_{3}$ in the anthraquinone intermediates I and II enhanced the $\mathrm{n}-\pi$ interaction, increased the conjugation and thus decreased the energy gaps of $\pi$ orbit, which lead to red-shift of maximum adsorption wavelength of polymeric dyes. In addition, the $-\mathrm{CH}_{3}$ in anthraquinone intermediates II increased the molecular polarity of polymeric dyes and $\pi$ electronic liquidity, decreased the activation energy $\Delta E$, which made the adsorption wavelength shifted to longer wavelength. Thus, the polymeric dye-2 showed a larger adsorption wavelength and more dark color than polymeric dye-1.

As reported that the molecular planarity also affected the adsorption wavelength, and when the entire atom in conjugation system were in the same plane, the maximum conjugative effect and largest overlap degree of $\pi$ electron cloud were obtained. The planarity of anthrapyridone group in polymeric dye3 and dye-4 was lower than that in polymeric dye-1 and dye-2, which lead to an increase in the activation energy $\Delta E$ and the blue-shift to the short adsorption wavelength. Thus, the polymeric dye-3 and dye-4 showed a shorter adsorption wavelength than the polymeric dye-1 and dye-2. Additionally, the benzene ring anthrapyridone group in polymeric dye-4 increased the conjugated system and the overlap degree of electronic orbit, which decreased the activation energy $\Delta E$. Thus, the polymeric dye-4 showed a longer adsorption wavelength than the polymeric dye-3. ${ }^{27,28}$

\section{Cytotoxicity studies}

The cytotoxicity of the anthraquinone intermediates and the prepared polymeric dyes were assessed by the in vitro cell cytotoxicity test against normal human liver cell lines LO2. The concentration required for $50 \%$ inhibition of cell viability $\mathrm{IC}_{50}$ was calculated and listed in Table 4 . The $\mathrm{IC}_{50}$ values of intermediates I-IV on LO2 were 1.018, 1.167, 1.218 and $1.204 \mathrm{~g} \mathrm{~L}^{-1}$ respectively. $\mathrm{IC}_{50}$ values for polymeric dye 1-4 on human liver cell lines LO2 was 7.666, 8.557, 8.186 and $8.934 \mathrm{~g} \mathrm{~L}^{-1}$ respectively. Obviously, the high $\mathrm{IC}_{50}$ values $\left(>7.6 \mathrm{~g} \mathrm{~L}^{-1}\right)$ suggested that the prepared polymeric dyes exhibited slight cytotoxicity and they could be safely applied in vivo as food additive. ${ }^{29}$

Cytotoxicity of polymeric dye 1-4 was studied using the MTT assay, and the results were shown in Fig. 4. The MTT assay showed a dose dependent response in normal human liver cell lines $\mathrm{LO} 2$, and the $\mathrm{LO} 2$ exposed to polymeric dye 1-4 showed high cell viability, which indicated lower toxicity of the prepared polymeric dye 1-4 towards normal cells.

Table $4 \quad I C_{50}$ values of the anthraquinone intermediates and the prepared polymeric dyes on human liver cell lines (LO2)

\begin{tabular}{lllllllll}
\hline Compounds & Intermediate I & $\begin{array}{l}\text { Polymeric } \\
\text { dye-1 }\end{array}$ & $\begin{array}{l}\text { Intermediate } \\
\text { II }\end{array}$ & $\begin{array}{l}\text { Polymeric } \\
\text { dye-2 }\end{array}$ & $\begin{array}{l}\text { Intermediate } \\
\text { III }\end{array}$ & $\begin{array}{l}\text { Polymeric } \\
\text { dye-3 }\end{array}$ & $\begin{array}{l}\text { Intermediate } \\
\text { IV }\end{array}$ & $\begin{array}{l}\text { Polymeric } \\
\text { dye-4 }\end{array}$ \\
$\mathrm{IC}_{50} \mathrm{~g} \mathrm{~L}^{-1}$ & 1.018 & 7.666 & 1.167 & 8.557 & 1.218 & 8.186 & 1.204 & 8.934
\end{tabular}



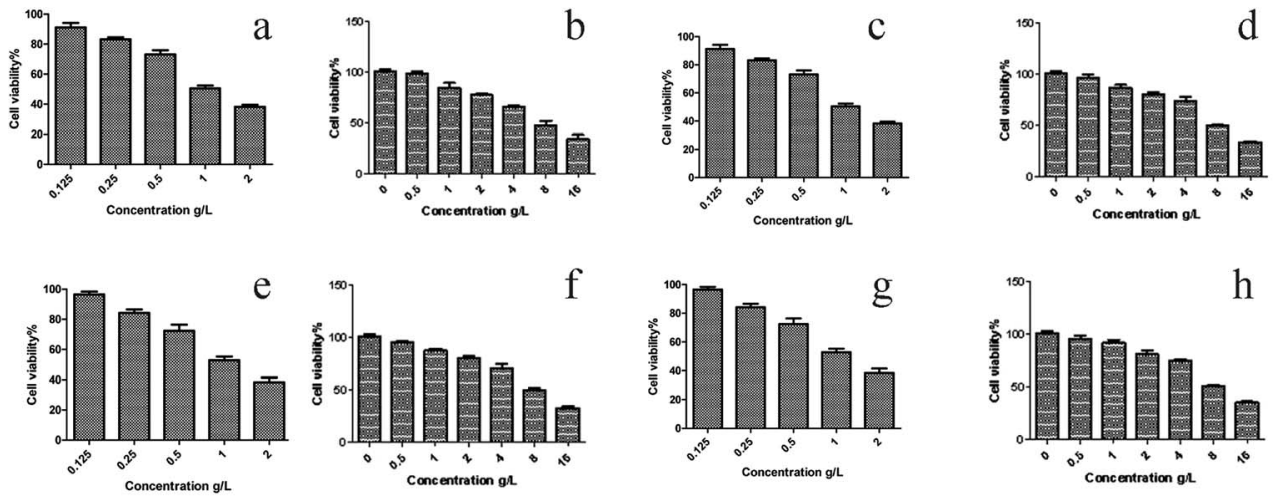

Fig. 4 Cell viability of normal cells (LO2) treated with: (a) intermediate I (b) polymeric dye-1; (c) intermediate II (d) polymeric dye-2; (e) intermediate III (f) polymeric dye-3; (g) intermediate IV (h) polymeric dye-4.

\section{Conclusions}

Four polymeric dyes were prepared by an Ullmann condensation reaction between brominated anthraquinone derivatives and $O$-carboxymethyl chitosan. The FT-IR, DSC and elemental analysis results showed that the anthraquinone derivatives were successfully grafted onto $O$-carboxymethyl chitosan, and the grafting degree of the four polymeric dyes were $0.66,1.14,0.93$ and $1.01 \mathrm{mmol} \mathrm{g}^{-1}$ respectively.

The color performance and UV-Vis spectra analysis results showed that the electronic property and planarity of substituent group in anthraquinone derivatives affected the adsorption wavelength of prepared polymeric dyes obviously, and the polymeric dyes with electron donating group and higher planarity showed longer adsorption wavelength and more dark color. The cytotoxicity test results revealed that $\mathrm{IC}_{50}$ values for the four prepared polymeric dyes on human liver cell lines LO2 were all higher than $7.6 \mathrm{~g} \mathrm{~L}^{-1}$, suggesting low cytotoxicity of prepared polymeric dyes.

\section{Experimental section}

\section{Materials}

Bromaminic acid (Industrial grade), Jiangsu Yabang Dyestuff Co., Ltd. 1-Methyl amino anthraquinone (Industrial grade), Jiangsu Aolunda High-tech Industry Co., Ltd. 1-Amino-2-methyl anthraquinone (AR) and $O$-carboxymethyl chitosan $\left(M_{\mathrm{w}}=\right.$ $200000 \mathrm{~g} \mathrm{~mol}^{-1}$ ), Shanghai Yuanye Bio-technology Co., Ltd. All the other reagents are analytical grade.

\section{Synthesis of polymeric dyes}

Synthesis of polymeric dye-1. Under magnetic stirring, $O$ carboxymethyl chitosan ( $0.66 \mathrm{~g}$ ) was added into $25 \mathrm{~mL}$ water, and the solution $\mathrm{pH}$ was adjusted to $10-10.5$ by sodium carbonate solution $(10 \%, \mathrm{w} / \mathrm{w})$. Then under $90{ }^{\circ} \mathrm{C}$, the bromaminic acid aqueous solution $(0.41 \mathrm{~g}$ intermediate I dissolved in $10 \mathrm{~mL}$ water) was added to the reaction mixture and heated to $100{ }^{\circ} \mathrm{C}$. Another $10 \mathrm{~mL}$ aqueous solution containing pentahydrate copper sulphate $(0.15 \mathrm{~g})$ and stannous chloride dihydrate $(0.06 \mathrm{~g})$ was added into the reaction mixture by three portions at a time interval of $1 \mathrm{~h}$. The mixture was refluxed for $8 \mathrm{~h}$. After filtration, the reaction mixture was distilled in reduced pressure at $50{ }^{\circ} \mathrm{C}$ to give concentrated solution, which was then purified by a dialysis experiment in distilled water to remove impurities with low molecular-weight using a benzoylated cellulose membrane (MWCO $3500 \mathrm{~g} \mathrm{~mol} \mathrm{~m}^{-1}$ ). The mixture in the membrane was condensed under reduced pressure and dried at $60{ }^{\circ} \mathrm{C}$ to give the final product polymeric dye-1 $(0.76 \mathrm{~g})$.

Synthesis of polymeric dye-2

(1) Preparation of 1-methylamino-4-bromoanthraquinone. In a $100 \mathrm{~mL}$ three-necked flask, 1-methylamino anthraquinone $(3.57 \mathrm{~g})$ and glacial acetic acid $(45 \mathrm{~mL})$ were mixed and stirred for $30 \mathrm{~min}$. Then the mixture was cooled down to $15^{\circ} \mathrm{C}$, and the bromine $(1.50 \mathrm{~g})$ was dropwise added into reaction mixture during 20 minutes. After reaction at $35{ }^{\circ} \mathrm{C}$ for $15 \mathrm{~h}$, additional bromine $(0.30 \mathrm{~g})$ was added. And then the mixture was heated to $50{ }^{\circ} \mathrm{C}$ and reacted for another $4 \mathrm{~h}$. After the reaction was completed, the reaction mixture was cooled to room temperature, filtered and washed with glacial acetic acid $(120 \mathrm{~mL})$ and deionized water, and then the obtained cake was added into 150 $\mathrm{mL}$ deionized water. Under stirring the sodium hydrogen sulfite (9 g) was added, and the mixture was heated and kept at $80{ }^{\circ} \mathrm{C}$ for $1 \mathrm{~h}$. Again, the reaction mixture was filtered, washed with deionized water and dried to obtain 1-methylamino-4bromoanthraquinone (intermediate II, $4.27 \mathrm{~g}$ ).

HPLC purity was 96.5\%; IR (KBr) 3434, 1665, 1596, 1551, 1514, 1433, 1357, 1265, 1194, 1118, 997, 718, 610, $550 \mathrm{~cm}^{-1}$; HRESIMS $m / z 315.9958[\mathrm{M}+\mathrm{H}]^{+}$(calcd for $\mathrm{C}_{15} \mathrm{H}_{11} \mathrm{BrNO}_{2}$, 315.9973).

(2) Synthesis of polymeric dye-2. The synthesis process of polymeric dye-2 was similar to that of polymeric dye-1. The difference was that when the reaction mixture was heated to $90{ }^{\circ} \mathrm{C}, 10 \mathrm{~mL}$ DMF was added, and the intermediate II (0.32 g) was dissolved in $15 \mathrm{~mL}$ DMF. The mixture was refluxed for $8 \mathrm{~h}$. After filtration, trimethylamine-sulphur trioxide complex (1.26 g) was added into the filtrate, the $\mathrm{pH}$ was kept at 10 by the addition of sodium carbonate solution (10\%) as necessary. After stirring at $70{ }^{\circ} \mathrm{C}$ for $24 \mathrm{~h}$ the reaction mixture was distilled in reduced pressure at $50{ }^{\circ} \mathrm{C}$ to obtain the concentrated solution of polymeric dye. All the other reaction conditions were the same 
as that shown in the synthesis process of polymeric dye-1, and the yield of polymeric dye-2 was $0.78 \mathrm{~g}$.

\section{Synthesis of polymeric dye-3}

(1) Preparation of 1-amino-2-methyl-4-bromoanthraquinone. The 1-amino-2-methyl-4-bromoanthraquinone was synthesized using the 1-amino-2-methyl-anthraquinone as original material and the synthesis process was the same as that shown in synthesis process of intermediate II. The dosage of 1-amino-2methyl anthraquinone and the yield were 2.42 and $2.71 \mathrm{~g}$ respectively.

1-Amino-2-methyl-4-bromoanthraquinone: HPLC purity was 98.5\%; IR (KBr) 3410, 1665, 1607, 1552, 1536, 1458, 1375, 1268, 1205, 1003, 973, 718, 620, $583 \mathrm{~cm}^{-1}$; HRESIMS m/z 314.9903 $[\mathrm{M}]^{+}$(calcd for $\mathrm{C}_{15} \mathrm{H}_{9} \mathrm{BrNO}_{2}, 314.9895$ ).

(2) Preparation of 3 -carbethoxy-2-methyl-4-bromo-1,9anthrapyridone. The mixture of 1-amino-2-methyl-4bromoanthraquinone $(0.95 \mathrm{~g})$, diethyl malonate $(1.9 \mathrm{~g})$, $\mathrm{Na}_{2} \mathrm{CO}_{3}(0.08 \mathrm{~g})$ and xylene $(15 \mathrm{~mL})$ was stirred at $140{ }^{\circ} \mathrm{C}$ for $8 \mathrm{~h}$, and the volatiles were removed with argon stream. After cooling, the product was filtered, washed with ethanol, hot water and ethanol again, and dried at $70{ }^{\circ} \mathrm{C}$ to give $3^{\prime}$ - carbethoxy-2-methyl-4-bromo-1,9-anthrapyridone (intermediate III, $1.1 \mathrm{~g})$.

HPLC purity was 98.4\%; IR (KBr) 2976, 1744, 1727, 1640, 1590, 1461, 1447, 1364, 1338, 1257, 1195, 1113, 927, 717, 648, $583 \mathrm{~cm}^{-1} ;{ }^{1} \mathrm{H}$ NMR (400 MHz, DMSO) $\delta 8.35(\mathrm{~d}, J=6.7 \mathrm{~Hz}, 1 \mathrm{H})$, $8.01(\mathrm{dd}, J=13.3,7.9 \mathrm{~Hz}, 2 \mathrm{H}), 7.89(\mathrm{t}, J=7.1 \mathrm{~Hz}, 1 \mathrm{H}), 7.81(\mathrm{~d}, J=$ $7.2 \mathrm{~Hz}, 1 \mathrm{H}), 7.67$ (d, $J=7.7 \mathrm{~Hz}, 1 \mathrm{H}), 4.48$ (q, $J=7.1 \mathrm{~Hz}, 2 \mathrm{H}), 2.57$ $(\mathrm{s}, 3 \mathrm{H}), 1.34(\mathrm{t}, J=7.1 \mathrm{~Hz}, 3 \mathrm{H})$. HRMS $m / z 409.9975[\mathrm{M}-\mathrm{H}]^{-}$ (calcd for $\mathrm{C}_{20} \mathrm{H}_{13} \mathrm{BrNO}_{4}, 410.0028$ ).

(3) Synthesis of polymeric dye-3. The synthesis process of polymeric dye- 3 was the same as that shown in the preparation process of polymeric dye-2. The dosage of 3 '-carbethoxy-2methyl-4-bromo-1,9-anthrapyridone and yield of polymeric dyes-3 were 0.41 and $0.82 \mathrm{~g}$ respectively.

\section{Preparation of polymeric dye-4}

(1) Synthesis of 6-bromo-4-methyl-1-phenylanthrapyridone. In argon atmosphere, 1-amino-2-methyl-4-bromoanthraquinone synthesized earlier $(4.74 \mathrm{~g})$ and toluene $(36 \mathrm{~mL})$ was added into a flask with magnetic stirring and condenser to obtain red slurry, and then the phenylacetyl chloride (2.94 g) was added. The mixture was heated to reflux for $6 \mathrm{~h}$, and then it was cooled

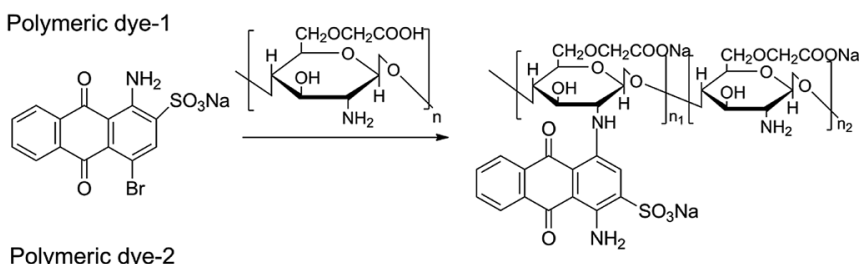

Polymeric dye-2
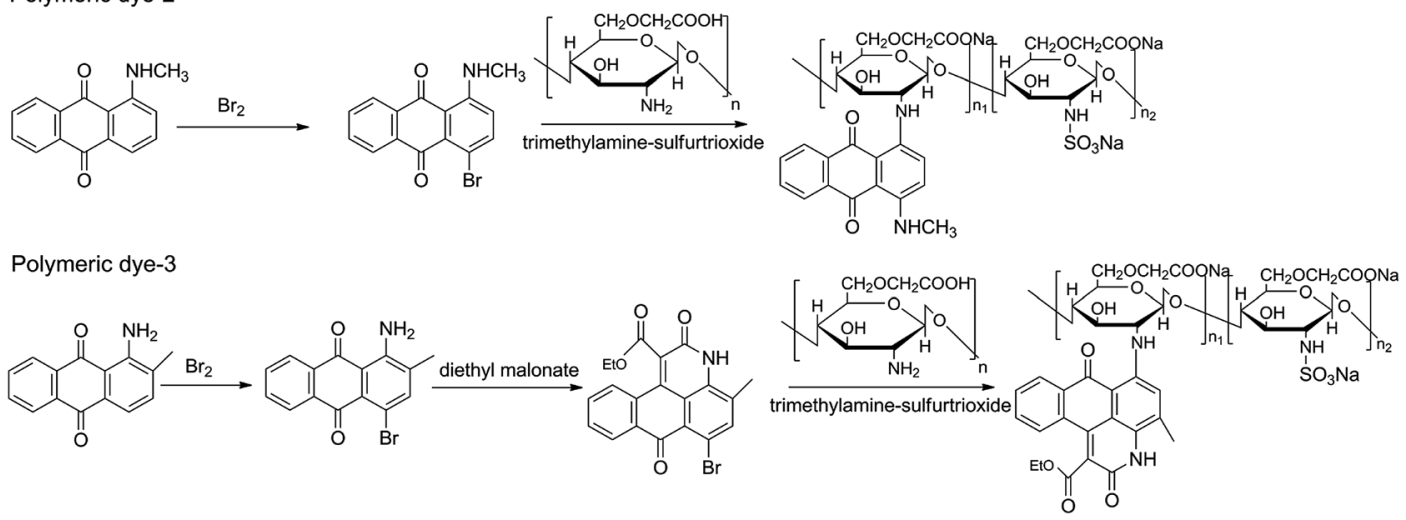

Polymeric dye-4
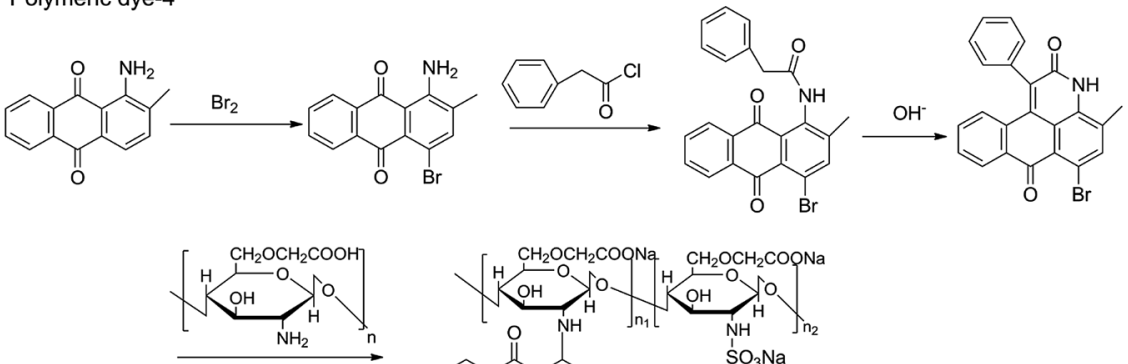

trimethylamine-sulfurtrioxide

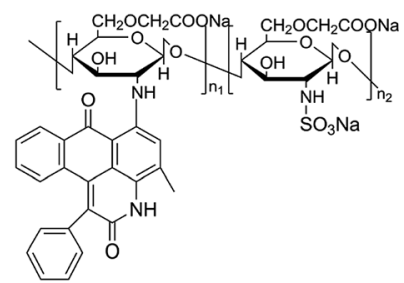

Fig. 5 Synthetic route of polymeric dyes 1-4. 
down to $60{ }^{\circ} \mathrm{C}$ and filtered. The obtained dark yellow filtrate was concentrated with a rotary evaporator, cooled to form a large amount of dark solid, which was separated, washed with ethyl acetate and dried in oven at $70{ }^{\circ} \mathrm{C}$ to give $3.94 \mathrm{~g}$ intermediate.

Under stirring, in a $50 \mathrm{~mL}$ three-necked flask equipped with water-cooled condenser and Ar inlet, the synthesized intermediate ( $3.2 \mathrm{~g}$ ) and ethylene glycol monomethyl ether $(22 \mathrm{~mL})$ was heated to $120{ }^{\circ} \mathrm{C}$, and then potassium hydroxide solution (0.32 $\mathrm{g} \mathrm{KOH}$ dissolved in $0.4 \mathrm{~mL} \mathrm{H}_{2} \mathrm{O}$ ) was added into the reaction system during $1 \mathrm{~min}$. After reaction for $3 \mathrm{~h}$, the reaction mixture was cooled down to $5{ }^{\circ} \mathrm{C}$, filtrated, washed with water and dried to obtain the yellow solid product $(1.22 \mathrm{~g})$. In addition, the filtrate was condensed by rotary evaporation to further recycle the solid product, which was recrystallized in $120 \mathrm{~mL}$ acetic acid, filtered and washed with water and dried to yield $1.30 \mathrm{~g}$ product. Thus, the total amount of the product 6bromo-4-methyl-1-phenylanthrapyridone (intermediate IV) was $2.52 \mathrm{~g}$.

HPLC purity was 96.3\%; IR (KBr): 3154, 3019, 1661, 1637, 1597, 1459, 1444, 1336, 1272, 1064, 925, 709, 628, $569 \mathrm{~cm}^{-1}$; HRMS $m / z: 414.0099[\mathrm{M}-\mathrm{H}]^{-}$(calcd for $\mathrm{C}_{23} \mathrm{H}_{13} \mathrm{BrNO}_{2}$, 414.0130). ${ }^{1} \mathrm{H}$ NMR (400 MHz, $\left.\mathrm{CDCl}_{3}\right) \delta 8.21(\mathrm{~s}, 1 \mathrm{H}), 7.76(\mathrm{~s}, 1 \mathrm{H})$, $7.37(\mathrm{~m}, 7 \mathrm{H}), 7.12(\mathrm{~m}, 1 \mathrm{H}), 2.56(\mathrm{~s}, 3 \mathrm{H})$.

(2) Synthesis of polymeric dye-4. Polymeric dye-4 was synthesized following the same procedure of polymeric dye-2 as mentioned earlier. The dosage of intermediate IV was $0.42 \mathrm{~g}$, and the yield of resulted polymeric dye- 4 was $0.81 \mathrm{~g}$. Based on what mentioned above, the synthesis routes of the prepared polymeric dyes were illustrated in Fig. 5 .

\section{Characterization of prepared polymer dyes}

The chemical structure of the prepared polymeric dyes was characterized by FT-IR spectrum (Nicolet i5, America). The UVVis spectra of the prepared polymeric dyes and anthraquinone intermediates were determined by a UV-Vis spectrophotometer (T9, Beijing Purkinje General Instrument Co., Ltd, China), and their thermal behavior was analyzed using differential scanning calorimetry (DSC, EV02, Rigaku Company, Japan) at a heating rate of $10^{\circ} \mathrm{C} \mathrm{m^{-1 }}$ from $30^{\circ} \mathrm{C}$ to $450{ }^{\circ} \mathrm{C}$. The grafting degree of the polymer dyes was analyzed by the elemental (C, H, N, S) analysis on a Vario EL III Elemental analyzer (Elementar, Germany).

\section{Cytotoxicity test of the prepared polymeric dyes}

Human normal liver cells (LO2) were purchased from the Cell Bank of Chinese Academy of Sciences (Shanghai, China). Confluent human normal liver cells (LO2) in good state were cultured in 96-well plates $\left(5-6 \times 10^{3}\right.$ cells per well) and treated with various concentrations of regents at $37^{\circ} \mathrm{C}$ for $24 \mathrm{~h}$. Then the cells were incubated with $10 \mu \mathrm{L}$ of $5 \mathrm{mg} \mathrm{mL}^{-1}$ MTT reagent for $4 \mathrm{~h}$ at $37^{\circ} \mathrm{C}$ and dissolved in $150 \mu \mathrm{L}$ dimethyl sulfoxide and shaken for $5 \mathrm{~min}$. Finally, the light absorption (OD) of the dissolved cells in reagent group and blank group was measured at $490 \mathrm{~nm}$ with soft Graphpad prism 5, then the $\mathrm{IC}_{50}$ values for the samples was calculated.

\section{Acknowledgements}

This work was financially supported by the National Natural Science Foundation of China (31201426).

\section{Notes and references}

1 B. Tang, S. Zhang, J. Yang and F. Liu, Dyes Pigm., 2006, 68, 69-73.

2 H. Mao, Y. Wang, D. Yao, C. Wang and S. Sun, RSC Adv., 2016, 6, 56831-56838.

3 H. Mao, F. Yang, C. Wang, Y. Wang, D. Yao and Y. Yin, RSC Adv., 2015, 5, 30631-30639.

4 L. A. Bunes, Polymeric aminoanthrapyridine orange colors, US 4206240 A, 1980.

5 P. Mpountoukas, A. Pantazaki, E. Kostareli, P. Christodoulou, D. Kareli, S. Poliliou, C. Mourelatos, V. Lambropoulou and T. Lialiaris, Food Chem. Toxicol., 2010, 48, 2934-2944.

6 E. M. Malik, M. Rashed, L. Wingen, Y. Baqi and C. E. Müller, Dyes Pigm., 2016, 131, 33-40.

7 H. Matsumoto and N. Kajiura, Anthrapyridone compound, magenta ink composition and colored matter, US 7727320, 2010.

8 Y. Caro, L. Anamale, M. Fouillaud, P. Laurent and T. Petit, Nat. Prod. Bioprospect., 2012, 2, 174-193.

9 J. S. Al-Otaibi and T. M. E. L. Gogary, J. Mol. Struct., 2017, 1130, 799-809.

10 The Council of Europe's Committee of Experts on Cosmetics products, Active ingredients used in cosmetics: safety survey, Council of Europe Publishing, 2008.

11 J. Wang, X. Qin, Z. Chen, Z. Ju, W. He, Y. Tan, X. Zhou, Z. Tu, F. Lu and Y. Liu, Phytochem. Lett., 2016, 15, 13-15.

12 Y. Cai, M. Sun, J. Xing and H. Corke, J. Agric. Food Chem., 2004, 52, 7884-7890.

13 G. Zengin, M. Locatelli, R. Ceylan and A. Aktumsek, J. Enzyme Inhib. Med. Chem., 2016, 31, 754-759.

14 G. Meazza, F. E. Dayan and D. E. Wedge, J. Agric. Food Chem., 2003, 51, 3824-3828.

15 M. Wuthi-udomlert, P. Kupittayanant and W. Gritsanapan, J. Health Res., 2010, 24, 117-122.

16 Q. Huang, G. Lu, H. M. Shen, M. Chung and C. N. Ong, Med. Res. Rev., 2007, 27, 609-630.

17 J. S. Al-Otaibi, P. T. Spittle and T. M. E. l. Gogary, J. Mol. Struct., 2017, 1127, 751-760.

18 T. Akihisa, K. Matsumoto, H. Tokuda, K. Yasukawa, K.-i. Seino, K. Nakamoto, H. Kuninaga, T. Suzuki and Y. Kimura, J. Nat. Prod., 2007, 70, 754-757.

19 K. Khan, R. Karodi, A. Siddiqui and S. Thube, Int. J. Appl. Res. Nat. Prod., 2011, 4, 875-889.

20 L. N. Sun, T. Han, L. Jiao, Q. Y. Zhang and J. Z. Wu, Molecules, 2009, 14, 573-583.

21 J. M. Zheng, J. M. Zhu, L. S. Li and Z. H. Liu, Br. J. Pharmacol., 2008, 153, 1456-1464.

22 D. Lv, M. Zhang, J. Cui, J. Lu and W. Li, New J. Chem., 2016, 40, 3363-3369. 
23 N. N. Inamdar and V. K. Mourya, Adv. Mater. Lett., 2010, 1, 11-33.

24 X. G. Chen, Z. Wang, W. S. Liu and H. J. Park, Biomaterials, 2002, 23, 4609-4614.

25 L. Upadhyaya, J. Singh, V. Agarwal and R. P. Tewari, Carbohydr. Polym., 2013, 91, 452-466.
26 X. Hu, X. Zhang, J. Liu and J. Dai, J. Lumin., 2013, 142, 23-27. 27 A. S. Abd-El-Aziz and T. H. Afifi, Dyes Pigm., 2006, 70, 8-17. 28 D. Liu and J. Liu, J. Mater. Cycles Waste Manage., 2014, 16, 557-565.

29 D. Lv, M. Zhang, J. Cui, W. Li and G. Zhu, Materials, 2017, 10, 219. 